\title{
A Brief Analysis of Sister Carrie's Character
}

\author{
Hanying $\mathrm{Yu}$ \\ Foreign Language Departmen \\ A Ba teachers College, Gu cheng, Pi Xian, Cheng du 611700, China \\ E-mail: babibabi98@yahoo.com.cn
}

\begin{abstract}
Carrie is always dreaming while the rocking chair is rocking again and again, this is the deep impression on us after we read Sister Carrie which is the first novel of Theodore Dreiser. In this novel the protagonist Sister Carrie is a controversial person. This paper tries to analyze the character of Sister Carrie in order to find out why what she has finally achieved is just extreme void and unhappiness, and shed light on how the author calls warmly for human intuitive knowledge, attacks vigorously the society of money omnipotent, and further more exposes bourgeois society's darkness.
\end{abstract}

\section{Keywords: Sister Carrie, Character}

Theodore Herman Albert Dreiser (1871-1945) is a great American naturalism writer in twenty century. Sister Carrie is his first novel which reflects the bourgeois social reality between later nineteen and early twenty century deeply and vividly. This novel describes that Carrie Meeber, namely, Sister Carrie, leaves her Wisconsin home to go to live with her married sister. She is young, beautiful but poor and she is full of ignorant and unrealistic fantasy to the better life in Chicago. After a short stay with her meager sister Minnie, she goes to live with Charles Drouet, a "drummer" or salesman, whom she meets on the train to Chicago, without marrying him. Then introduced by Drouet, she meets George Hurstwood, the manager of a famous and deluxe salon. Eventually, Hurstwood, a family man is infatuated with her and tricks her into leaving Chicago with him. He finances this expedition and their subsequent life together in New York - after a pretended marriage — with money he has stolen from his Chicago employer. The remainder of the novel details Hurstwood's subsequent personal decline and eventual suicide and Carrie's rise in the world of musical entertainment.

After we finish reading this novel, Carrie's always dreaming while the rocking chair is rocking again and again may leave a deep impression on us. Our author integrates the rocking chair with Carrie who is full of fancy is much food for thought. Carrie is the main character of the novel. She was born in a working family of a flour mill. To our opinion, Carrie should be a hard-working girl. But she is infected with the bad habits of the petty bourgeoisie and isn't satisfied with her life in narrow country. She is completely frank about her desire for a better life, beautiful clothes, more money and a higher position. She thinks that she can find all these in the big city-Chicago, which in those days was like a magnet attracting many young people in the middle and west parts of America. They try to find happiness in the urban society. In fact, the city is just like a gambling house in which a few people succeed by accident while many are always struggling at the bottom of the society. In addition, the beauty of the city is an illusion and a trip which "Like music, too often relax, weakens, then perverts the simple human perceptions.”(Dreiser, 1988, p.2) Carrie, an eighteen-year-old country girl, doesn't know about this.

At the beginning of the novel, we know that Carrie is a bright and timid girl. She is full of the illusions of ignorance and youth. She is possessed of a rudimentary mind in its power of observation and analysis. Self-interest with her is high, but not strong. It is, nevertheless, her guiding characteristic. She is vain and dreaming all day long to move up. She is a typical example of the Middle American class - two generations who removed from the emigrants. Books are beyond her interest - knowledge a sealed book. And yet she is interested in her charms, quick to understand the keener pleasure of life, ambitious to gain in material things. So this half-equipped little knight involved in the search for the American Dream, "venturing to reconnoiter the mysterious city and dreaming wild dreams of some vague, far-off supremacy, which should make it prey and subject, the proper penitent, groveling at a woman's slipper." (Dreiser, 1988, p.2)

Being full of such unformulated desires and with no firm moral principles, Carrie goes to Chicago for work. According to Dreiser, Carrie becomes either someone under another's care and protecting "falls into saving hands and becomes better" or the victim of a voracious city. There is no middle ground. In either case, it is apparent that Carrie has little control over her life. First, she meets Drouet, a cheap lady-killer in flashy clothes. "He reached down in his hip pocked and took out a fat purse. It was filled with slips of paper, some mileage 
books, a roll of green backs." (Dreiser,1988, p.5) This impresses her deeply as such a purse has never been carried by any one attentive to her. Then Carrie, after a dreary round of job-hunting, with the sense of loss and depersonalization in the swarming city, is easy to be the prey of Drouet. When Drouet gives her twenty dollars, she accepts it without thinking carefully. What she thinking is "Oh, money, and money, how nice it is, more money, life is easier", Money itself is power. She considers many times that it would be better when she had the twenty dollars and she thinks as long as she had much money possessed, she would willingly be thrown to the desert island. So she finally yields to the moral standard of the unban society. Later, with her blind aspiration toward something more glittering and more real, she is easy to be the prey of Hurstwood who stands at a higher level. Drouet being closer to some center of power, wealth, and joy, the poor Carrie cannot actually conceive but merely sense. Carrie embarks on the road of degeneration and becomes two men's mistress, the reasons are complicated. On one hand, Carrie is forced to go to by the hard life of the lower class people in bourgeois society; on the other hand, she is full of wonder even to be greedy. Some emphasize the former while some emphasize the latter.

To be sure, there are some objective reasons about her degeneration. For example, she loses her job because of three day's illness and can't find one again. But the subjective and essential factor is her greed for the material things. We can see Carrie, after several days in Chicago, "realized in a dim way how much the city held wealth, fashion, ease, every adornment for women, and she longed for dress and beauty with a whole heart." (Dreiser, 1988 , p.18) She feels that her sister's home was 'a narrow, humdrum place, and that interest and joy lay elsewhere'. Although she is in the shoes factory, she thinks of "the city outside and its imposing show, crowds, and fine building." (Dreiser, 1988, p.33)

From the information above, we can see Carrie's degeneration is inevitable. Her illness, unemployment and hard life are just small incidents that touch off a big one. Carrie can not resist the temptation from Drout. Event if she didn't lose her job, she would still leave the factory and her sister's home, and then threw herself into Drout. The author uses a dream of Minnie (Carrie's sister) to indicate this point.

Some People say that if Hurstwood didn't cheat Carrie, she would not live with him. In fact, this is not convincing. Hurstwood doesn't purposely tell Carrie that he is a married man and Drouet doesn't tell her about this either. Cheating her, Hurtwood takes Carrie to flee to New York. There are some conflicts and contradictories in Carrie herself. However, she has been fascinated by Hurstwood's wealth, social position and demeanor. According to her own opinion, she feels "It was an important thing to her to hear one so well-positioned and powerful speaking in this manner..., and here was this greatest mystery, the man of money and affairs sitting beside her, appealing to her. Behold, he has ease and comfort, his strength was great, his position high, his clothing rich, and yet he was appealing to her."(Dreiser, 1988, p.103) "She could not help feeling the strangeness of her situation." (Dreiser, 1988, p.103) So although she knows that she was cheated by him later she is still reluctant to leave him. We can imagine even if Hurstwood didn't cheat her, she would eventually have abandoned Drouet and come to Hurstwood, and she would have abandoned Hurstwood as well when she had higher pursuit for material things.

Let's see the other aspects in Carrie's nature. In some way, she is quite cruel. Having left her sister, she doesn't go back to see her again. For the sake of her gain and lose, she abandons Drouet and Hurstwood one by one without any mercy. In New York, Carrie finds a job and has some money, but she is unwilling to support the family with her own money. "Her need of clothes - to say nothing of her desire for ornaments-grew rapidly as the fact developed that for all her work she was not to have them. The sympathy she felt for Hurstwood, at the time he asked her to tide him over, vanished with these newer urgings of decency" (Dreiser, 1988, p.308). We say Carrie is cruel, however, she has some sympathy at the same time: When she sees the toilers in under-world, she pities from the depths of her heart. When Hurstwood decides to look for a job in Brooklyn during the strike time, Carrie feels very sorry.

In this novel, we can see Carrie is passive. She makes a little progress. In the chapter "A Pilgrim, An outlaw, The Spirit Detained" Dreiser continues to think of Carrie as an ignorant but slowly wakening seeker after deeper significance in life. The first chapter after their arrival in New York is "The kingdom of Greatness, The Pilgrim, A Dream" But it is only after Hurstwood has drifted far into the maelstrom of misfortune that she realizes that she must strike out for herself, and thinks of trying her lot on the stage. In a chapter headed "The Spirit Awakens. New Search for the Grate" It is only at the end of the novel that she begins to have the cognitive ability. She has seen through her tinsel pleasures with Drouet. She has grown beyond the sphere of Hurstwood. And she finds herself essentially solitary, although she has money, fame and gowns, which she has pursued all the time. She is not happy. Dreiser takes leave of her, saying: "Now then, that you are neither surfeit nor content. In your rocking-chair by your window dreaming, shall you long, alone. In your rocking-chair by your window, shall you 
dream such happiness as you may never feel?" (Dreiser, 1988, p.382)

When Carrie has come to the upper society, she feels empty and lonely, why? We can get the answer from the end of the story. "Chicago dawning, she saw the city offering more of loveliness than she had ever known, and instinctively, by force of her moods alone, clung to it. In fine raiment and elegant surroundings, man seemed to be contended, hence, she drew near those things. Chicago, New York; Drouet, Hurstwood; the world of fashion and the world of stage - these were but incidents. Not them, but that which they represented, she longed for. Time proved the representation false." (Dreiser, 1988, p.381) Then she learns that in their world, as in her own present state, there isn't happiness. The rocking chair is rocking but not going forward. Life is just a repetition and a dream which lacks substance or content. They have achieved nothing. This is an extreme satire on American Dream which is boosted extremely by the bourgeoisie at that time. This part is quite important. If it is omitted, the character of Sister Carrie will be misrepresented.

However, there is positive factor in Carrie, when she is just eighteen years old, she isn't content with the narrow town and is anxious to change her unfavorable situation, and then she goes to Chicago for work by herself. At this point, we may say she is somewhat strong, but she longs for the glittering life and doesn't want to get it by hard-working, taking a wrong step to be the rich men's mistress, it seems that the positive significance has vanished from her.

We can see Carrie is a pretty young girl whom Dreiser uses to express his own longings for wealth and affection. The glitter and excitement of the city has come to symbolize the possibility for the realization of the American Dream. Dreiser himself had been born in poverty. When he was young, he did odd jobs to subsidize his family spending. He became a newspaper boy, a shop assistant, a lower clerk etc. Therefore he doesn't regard her as sinful. In his novel, Dreiser emphasizes the determinism. The mechanical power makes everything inevitable. Carrie rises to be a successful theatrical star from a country girl and accedes to the bourgeois upper class; Hurstwood sinks to ruin from a manager to be a beggar and eventually suicide. All this can't show the individual power or powerlessness. On the contrary, it is the mechanical power that pushes them to that position. What the author wants to say is that there is no cause-result relationship between diligence and success, and people cannot control over her life in bourgeois society.

Now we know that the image of Carrie is quite complicated. We can draw this conclusion that Carrie is a victim of 'Desire' and 'Society'. Her degeneration is something beyond her control. After you read the novel, I think Carrie's fantasy — pursuit_-vacillation_-disillusion will make a deep impression on you.

\section{References}

Brooks, Cleanthes and Warren, Lewis. (1973). American Literature the Makers and the Making, Volume II. New York: St. Martin's Press..

Caniff, Marcus. (1986). The Literature of the U.S. New York: Viking Penguin Inc.

Dreiser, Theodore. (1988). Sister Carrie. New York: Bantam Books.

Mednick, Fred. (1905). An Introduction to American Literature. Henan: Henan University press. 